SVU-International Journal of Veterinary Sciences, 1 (1): 102-113, 2018

Print ISSN: 2535-1826

Online ISSN: 2535-1877

Research Article

Open Access

\title{
Some Virulence Genes of Pathogenic Enterococci Isolated from Raw Milk and Some Milk Products
}

Margret Y. Shafeek*, Laila M. El-Malt, Karima G. Abdel Hameed and Mona A. El-Zamkan

Department of Food Hygiene, Faculty of Veterinary Medicine, South Valley University, Qena

$$
\text { 83523, Egypt }
$$

\begin{abstract}
A total of 150 random samples of raw cow milk and some locally manufactured dairy products including yoghurt, Kareish cheese and ice cream were collected from various dairy shops, and supermarkets in Qena city, Egypt. Samples were examined for the presence of Enterococcus spp. The investigation revealed that $64,28,76,72$ and $16 \%$ of the examined raw milk samples, large and small-scale yoghurt, Kareish cheese and ice cream were contaminated with Enterococcus spp., respectively. Isolates were identified as E. faecalis and E. faecium in percentages of $(8 \& 32),(16 \& 0),(8 \& 28),(8 \& 36)$, and $(4 \& 0)$ in the examined raw milk samples, large and small-scale yoghurt, Kareish cheese and ice cream, respectively. The obtained isolates were screened for presence of some virulence genes gelE, asa1, esp and cylA using multiplex PCR. The results indicated that gelE, asa1, esp and cylA were located in 53.9, 76.9, 69.2, and $30.8 \%$ of the total $\mathrm{E}$. faecalis isolates and in 46.9, 71.9, 53.1 , and $34.3 \%$ of the total E. faecium isolates, respectively. The asa1 and esp genes were the predominant virulence traits among all investigated enterococci isolates followed by gelE and cylA genes. Therefore, the results of this study showed that milk and dairy products can play an important role in the spread of Enterococci with virulence potential through the food chain to the human population.
\end{abstract}

Keywords: Enterococcus spp., milk, dairy products, PCR, virulence genes

Received: June 20, $2018 \quad$ Accepted: June 28, 2018

Published: June 30, 2018

*Corresponding Author: Margret Y. Shafeek

E-mail: margret_yousry@yahoo.com

Citation: Shafeek et al., 2018. Some Virulence Genes of Pathogenic Enterococci Isolated from Raw Milk and Some Milk Products. SVU-IJVS, 1 (1): 102-113.

Copyright: (c) This is an open access article distributed under the terms of the creative common attribution license, which permits unrestricted use, distribution and reproduction in any medium provided the original author and source are created.

Competing interest: The authors have declared that no competing interest exists. 


\section{Introduction}

The genus Enterococcus is Grampositive, catalase and oxidase negative, non-spore-forming, facultative anaerobic bacteria that can occur both as single cocci and in chains. Enterococci belong to a group of organisms known as lactic acid bacteria (LAB) that produce bacteriocins (Thurlowet al., 2009 and VanTyne and Gilmore, 2014). Enterococci often occur in large numbers in soil, water, in the gastrointestinal tract of animals and humans, and foods especially those of animal origin such as milk and dairy products (Franz et al.,1999). The ability of Enterococci to colonize different ecological niches and spreading within the food chain is due to their resistance to the adverse environmental conditions (Giraffa, 2002). Enterococcus spp. has become one of the most common nosocomial pathogens especially in immunosuppressed patients with a high mortality rate of up to $61 \%$ (Pohet al., 2006). Enterococci have been implicated in cases of food poisoning, e.g. by production of biogenic amines. Food intoxication caused by ingestion of biogenic amines determines a number of symptoms which include headache, vomiting, increase of blood pressure and even allergic reactions of strong intensity (Giraffa, 2002). Enterococci may carry various genes such as aggregation substances (asa1), endocarditis antigen, gelatinase (gelE), Extracellular surface protein (esp), Cytolysin (cylA) and hyaluronidase or adhesion collagen protein have been described in enterococci isolated from foods (Hammad, et al.,2015). The presence of virulence genes in foods is currently a matter of concern because Enterococci may be involved in the transmission of virulence genes via the food chain (Trivediet al., 2011). Therefore, this study put a focus on isolation and identification of Enterococcus spp. from raw milk and some milk products as well as detection of some virulence genes by multiplex PCR.

\section{Materials and Methods}

products including yoghurt (25 large scale and 25 small scale samples), Kareish cheese (25 samples) and ice cream (25 samples) were collected from various dairy shops, and supermarkets in Qena city, Egypt. These samples were transferred to the laboratory without delay to be examined. Heat treated milk was detected by Storch test (Lampert, 1975).

1. Samples preparation: were done according to (A.P.H.A., 1992)

2. Enumeration and isolation of Enterococcal isolates: were done according to (Deibel and Hartman, 1982).

3. Identification of Enterococcal isolates

3.1. Microscopical examination: (A.P.H.A., 1992)

3.2. Biochemical identification: was done according to Morrison et al., (1997) and Manero and Blanch (1999).

4. Detection of some virulence genes in E. faecalis and E. faecium isolated from the examined samples by multiplex PCR (Dogru et al., 2010)

4.1 DNA Extraction and PCR amplification

DNA extraction from samples was carried out using the QIAamp DNA 
Mini kit (Qiagen, Germany) according to the manufacture's recommendations. The DNA amplification was performed using the oligonucleotide primers recorded in Table 1 as described by (Dogruet al., 2010). The reaction was conducted in a thermal cycler. The cycling parameters were an initial denaturation at $95{ }^{\circ} \mathrm{C}$ for $10 \mathrm{~min}$, followed by 30 cycles of denaturation $\left(94{ }^{\circ} \mathrm{C}\right.$ for $\left.1 \mathrm{~min}\right)$, annealing $\left(56^{\circ} \mathrm{C}\right.$ for $1 \mathrm{~min})$, extension $\left(72^{\circ} \mathrm{C}\right.$ for $\left.1 \mathrm{~min}\right)$, and a final extension step at $72{ }^{\circ} \mathrm{C}$ for 10 min. The PCR reaction was performed in a mixture of $25 \mu \mathrm{l}$. The reaction mix consisted of $2.5 \mu \mathrm{L}$ of bacterial lysate, $2.5 \mu \mathrm{L}$ of Template DNA, $5 \mu \mathrm{l}$ of $10 \mathrm{x}$ assay buffer for Taq polymerase containing $1.5 \mathrm{mM} \mathrm{MgCl} 2,2 \mu \mathrm{l}$ of $10 \mathrm{mM}$ dNTP mix, $1 \mu 1$ each of forward and reverse primer $(10 \mathrm{pmol})$ and $2.5 \mathrm{U}$ of Taq DNA polymerase.

\subsection{Detection of PCR products:}

PCR products were analyzed by electrophoresis on $1.5 \%$ agarose gel stained with ethidium bromide and Figgraphed under UV light.

\section{Results and Discussion}

Enterococci are commonly encountered in raw milk and dairy products including even those undergo heat treatment. Their ability to withstand processing conditions renders them potentially important from the public health point of view as their presence is indicative of fecal contamination (Brooks, 1974). According to data presented in Table 2, Enterococci was counted in $64 \%$ of the raw cow milk samples with an average count of 7.5 $\times 107 \mathrm{cfu} / \mathrm{ml}$. Abd El-Hameid (2002), Abd El-Rahman (2010), Mohammad (2015) and Abd El Tawab et al., (2016) recorded higher incidences of Enterococci in dairy shops raw milk which reached 100, 83.3, 66 and 76\%, respectively. While lower incidence $(60 \%)$ was reported by Elmali and Hayriye (2018). The isolated Enterococci spp. recovered from the tested raw cow milk samples were biochemically identified as E. faecalis $(8 \%)$, E. faecium (32\%) as recorded in Table 3. Occurrence of Enterococci in milk is due to their wide distribution in nature hence it may contaminate milk through the contaminated water supply, equipment and unhygienic conditions during production and handling through the journey of milking to reach the consumer. They have been incriminated as direct or indirect cause of disease and food poisoning because of their ability to produce extracellular toxic metabolites (Roushdy et al., 1998). Regarding large scale yoghurt samples, the data summarized in Table (2) postulated that $28 \%$ of the examined samples were contaminated with Enterococci in counts ranged from < 102 to $2.4 \times 105$ with an average count of $64.8 \times 103 \mathrm{cfu} / \mathrm{g}$. Higher incidences $40 \%$ and counts $4.7 \times 104 \mathrm{cfu} / \mathrm{g}$ was reported by Abd El-Rahman (2010). On the other hand, Abd El-Aal, (2008) demonstrated lower incidence of $20 \%$, and lower counts of Enterococci7.3 $\times 10$ and $1.4 \times 103 \mathrm{cfu} / \mathrm{g}, \quad$ respectively. Concerning small scale yoghurt samples, it was found that $76 \%$ of the examined samples were contaminated with Enterococci with a minimum of $<102$, a maximum of $4.5 \times 108 \mathrm{cfu} / \mathrm{g}$ and an average value of $83.6 \times 105 \mathrm{cfu} / \mathrm{g}$. Lower incidences of 60 and $52 \%$ were reported by (Ahlam, et al., 2015) and Abd El Tawabet al., (2016) respectively. Higher incidence $(77.5 \%)$ and lower count of $(15.4 \times 103 \mathrm{cfu} / \mathrm{g})$ 
was reported by Al-Hawary (2000). In contrary with the obtained results, lower incidences and counts were recorded by El-Malt et al., (2013b), ElAnsary (2014) and Gorgy et al., (2016), where they could isolate Enterococci from small scale yoghurt in percentages of 58,28 and $32 \%$, with counts of $1.7 \times 104,5.8 \times 104 \pm 5.43 \times 103$ and $5.5 \times 103 \pm 0.64 \times 103 \mathrm{cfu} / \mathrm{g}$, respectively. The existence of Enterococci in yoghurt is indicator of neglected sanitary measures during production and distribution. Moreover, Enterococcus able to survive the unfavorable microenvironment as the low $\mathrm{pH}$ value of yoghurt and other types of fermented milk (El-Ansary, 2014). The results obtained in Tables 2 revealed that (72\%) 18 out of the 25 examined Kareish cheese samples were contaminated with Enterococci at levels varied from $<102$ to $1.8 \times 108$ with an average count of $3.94 \times 107 \mathrm{cfu} / \mathrm{g}$. Enterococci could be isolated in higher incidences and lower counts by Abd ElRahman (2010) and Mohammad (2015).They isolated Enterococci in percentages of 83.3 and $86.7 \%$ with counts of $1.5 \times 106$ and $3.4 \times 106 \mathrm{cfu} / \mathrm{g}$. respectively. Likewise, Ahlam et al., (2015) and Abdeen (2016) recovered higher incidence 86.6 and $90 \%$, respectively. On contrary, Hussien et al., (2013) and Gorgy et al., (2016) recorded lower incidence 65.7 and $36 \%$ and count $2.4 \times 106$ and $5.7 \times 103 \pm 1.6 \times 103 \mathrm{cfu} / \mathrm{g}$. respectively. High contamination levels of Enterococci are considered to cause the deterioration of organoleptic properties in some cheese (Lopez-Diaz et al., 1995). The obtained high levels of Enterococci in Kareish cheese samples may be contributed to the lack of pasteurization of milk. Also, the production of Kareish cheese in Egypt is generally a house-hold process which takes place under poor sanitary practices during manufacturing, handling, storage and distribution of cheese that may constitute a public hazard and induce food poisoning. According to the data presented in Tables 2, it was found that $16 \%$ of the examined ice cream samples were contaminated with Enterococci with an average value of $1 \times 104 \mathrm{cfu} / \mathrm{g}$. Higher incidences (54\%) and lower count (6.9x $103 \mathrm{cfu} / \mathrm{ml}$ ) were recorded by El-Malt et al., (2013a). The presence of Enterococci in ice cream samples seems to be illegal, because no acceptable level of these microorganisms could be present. Their occurrence may be attributed to post- manufacture contamination, heat resistance character of the organism and contamination during packaging or improper methods of distribution. Furthermore, at below freezing temperature, Enterococci remained viable for long periods and able to multiply at temperature below 4.5 and $10^{\circ} \mathrm{C}$ (Angelottiet al., 1963). Several studies have recently shown that Enterococci spp. possess putative virulence factors that play important role in its pathogenesis such as gelatinase (gelE), aggregation substance (asa1), extracellular surface protein (esp) and cytolysin (cycl A) (Barbosa et al., 2010). E. faecalis and E. faecium remain the species of greatest importance amongst the different Enterococci spp. that found in milk and dairy products, so the present study focused on detection of some virulence genes in these two species because virulence genes may be transmitted via the food chain (Trivediet al., 2011). Data presented in Table (3), and Figs (1 $\& 2$ ) showed that the gelE gene was 
found in 50 and $62.5 \%$ of E. faecalis and E. faecium isolates from raw milk submitted to PCR. Similar result was reported by Hussein (2013) while, higher incidence (86\%) obtained by Inhoque et al., (2017). Lower incidences of gelE (33.3 and 17.24\%) in E. faecium were reported by $\mathrm{Abd} \mathrm{El}$ Tawab et al., (2016) and Inhoque et al., (2017). In the present study the gelE gene was detected in a total of 50 $\$ 42.9 \%$ of E. faecalis and E. faecium strains isolated from yoghurt samples, respectively (Table 3 and Figs 1\&2). The same incidence of gelE gene in $\mathrm{E}$. faecalis isolates was reported by $\mathrm{Abd} \mathrm{El}$ Tawab et al., (2016). From data illustrated in Table (3), and Figs (1\& 2), the gelE gene was found in 50 and 22.2 $\%$ of $\mathrm{E}$. faecalis and E. faecium isolates from Kareish cheese samples, respectively. Also, Gomes et al., 2008 recorded higher incidences $(95.1 \%)$ of gelE of E. feacalis. The gelE gene was detected in all investigated $\mathrm{E}$. faecalis obtained from large scale ice cream samples, while none of $E$. faecium harbored gelE virulence gene Table (3), and Figs (1\&2). Aggregation substance (asa1) is a surface protein adhesion encoded by asal and is exclusively found in E. faecalis strains however, its incidence among food isolates seems to be high (Franz et al., 2001). The present study showed that all $\mathrm{E}$. faecalis isolates obtained from raw cow milk carried asa1 gene, while $75 \%$ of E. faecium strains isolated from raw milk were positive for presence of asal gene
(Table 3 and Figs 1\&2). Lower incidence was recorded by Hussein (2013), Hosseini et al., (2016) and Inhoque et al., (2017) as they detected asa1 gene in $75,84.6$ and $26 \%$ of E. faecalis, respectively. As well, the asa1 gene was found in a total of $66.7 \& 57.1$ $\%$ of E. faecalis and E. faecium strains isolated from yoghurt samples, respectively. Abd El Tawab et al., (2016) found that none of E. faecalis obtained from yoghurt samples harbored asa1 gene. Regarding Kareish cheese samples asa1gene was found in $50 \& 77.8 \%$ of $\mathrm{E}$. faecalis and $\mathrm{E}$. faecium, respectively. Hosseini et al., (2016) detectedasal gene in all $\mathrm{E}$. faecalis strains obtained from dairy cheese, While Gomes et al., (2008) recorded lower incidence of $\mathrm{E}$. faecalis asa1 gene 26.8. Higher incidence $80 \%$ of asa1 genes in E. faecium was reported by Hosseini et al., (2016). The asa1 gene was detected in all investigated $\mathrm{E}$. faecalis isolates from large scale ice cream samples, while

The present study showed that esp gene was found in $66.7 \& 71.4 \%$ of E. faecalis and E. faecium strains obtained from yoghurt samples, respectively Table (3). Higher results obtained by Abd El Tawab et al., (2016) as he found that all E. faecalis isolates obtained from yoghurt samples harbored esp gene. None of virulence genes was recorded for E. faecium in large scale yoghurt samples.

Table 1. Primer sequences used for PCR

\begin{tabular}{|c|c|c|c|c|c|}
\hline $\begin{array}{c}\text { Target } \\
\text { gene }\end{array}$ & $\begin{array}{c}\text { Virulence } \\
\text { factor }\end{array}$ & Oligonucleotide sequence $\left(5^{\prime} \rightarrow 3^{\prime}\right)$ & $\begin{array}{c}\text { Primer } \\
\text { name }\end{array}$ & $\begin{array}{c}\text { Product } \\
\text { size (bp) }\end{array}$ & References \\
\hline
\end{tabular}




\begin{tabular}{|c|c|c|c|c|c|}
\hline $\begin{array}{c}\text { gelE } \\
(\mathbf{F})\end{array}$ & \multirow{2}{*}{ Gelatinase } & 5' TATGACAATGCTTTTTGGGAT '3 & GEL 11 & \multirow{2}{*}{213} & \multirow{4}{*}{$\begin{array}{c}\text { Vankerckhoven et } \\
\text { al., (2004) }\end{array}$} \\
\hline $\begin{array}{c}\text { gelE } \\
(\mathbf{R})\end{array}$ & & $\begin{array}{c}5^{\prime} \text { AGATGCACCCGAAATAATATA } \\
3\end{array}$ & GEL 12 & & \\
\hline $\begin{array}{c}\text { asal } \\
(\mathbf{F})\end{array}$ & \multirow{2}{*}{$\begin{array}{l}\text { Aggregation } \\
\text { substance }\end{array}$} & $\begin{array}{c}5^{\prime} \text { GCACGCTATTACGAACTATGA } \\
33\end{array}$ & $\begin{array}{c}\text { ASA } \\
11\end{array}$ & \multirow{2}{*}{375} & \\
\hline $\begin{array}{c}\text { asa1 } \\
(\mathbf{R})\end{array}$ & & $\begin{array}{c}5^{\prime} \\
\text { TAAGAAAGAACATCACCACGA'3 }\end{array}$ & $\begin{array}{c}\text { ASA } \\
12\end{array}$ & & \\
\hline $\operatorname{esp}(\mathbf{F})$ & \multirow{2}{*}{$\begin{array}{c}\text { Enterococcal } \\
\text { surface } \\
\text { protein }\end{array}$} & $\begin{array}{c}5^{\prime} \\
\text { AGATTTCATCTTTGATTCTTGG'3 }\end{array}$ & $\begin{array}{l}\text { ESP } \\
14 \mathrm{~F}\end{array}$ & \multirow{2}{*}{510} & \multirow{2}{*}{$\begin{array}{l}\text { Willems et al. } \\
\qquad(2001)\end{array}$} \\
\hline $\operatorname{esp}(\mathbf{R})$ & & 5' AATTGATTCTTTAGCATCTGG '3 & $\begin{array}{l}\text { ESP } \\
12 R\end{array}$ & & \\
\hline $\begin{array}{c}\text { cylA } \\
(\mathbf{F})\end{array}$ & \multirow{2}{*}{ Cytolysin } & $5^{\prime}$ ACTCGGGGATTGATAGGC'3 & CYT I & \multirow{2}{*}{688} & \multirow{2}{*}{$\begin{array}{l}\text { Coque et al., } \\
\quad(1995)\end{array}$} \\
\hline $\begin{array}{c}\text { cylA } \\
(\mathbf{R})\end{array}$ & & 5' GCTGCTAAAGCTGCGCTT'3 & $\begin{array}{c}\text { CYT } \\
\text { IIb }\end{array}$ & & \\
\hline
\end{tabular}

Table 2. Statistical analytical results of Enterococcus spp. in the examined raw milk, yoghurt, Kareish cheese and ice cream samples

\begin{tabular}{|c|c|c|c|c|c|c|}
\hline \multirow{2}{*}{$\begin{array}{l}\text { Type of } \\
\text { samples }\end{array}$} & \multirow{2}{*}{$\begin{array}{c}\text { No. of } \\
\text { examined } \\
\text { samples }\end{array}$} & \multicolumn{2}{|c|}{$\begin{array}{l}\text { Positive } \\
\text { samples }\end{array}$} & \multicolumn{3}{|c|}{ Count/g or ml } \\
\hline & & No. & $\%$ & Minimum & Maximum & Average \\
\hline Raw milk & 50 & 32 & 64 & $*<10^{2}$ & $4.3 \times 10^{8}$ & $7.5 \times 10^{7}$ \\
\hline $\begin{array}{c}\text { Large scale } \\
\text { yoghurt }\end{array}$ & 25 & 7 & 28 & $*<10^{2}$ & $2.4 \times 10^{5}$ & $64.8 \times 10^{3}$ \\
\hline $\begin{array}{c}\text { Small scale } \\
\text { yoghurt }\end{array}$ & 25 & 19 & 76 & $*<10^{2}$ & $4.5 \times 10^{8}$ & $83.6 \times 10^{5}$ \\
\hline Kareish cheese & 25 & 18 & 72 & $*<10^{2}$ & $1.8 \times 10^{8}$ & $3.9 \times 10^{7}$ \\
\hline $\begin{array}{l}\text { Large scale Ice } \\
\text { cream }\end{array}$ & 25 & 4 & 16 & $*<10^{2}$ & $3.9 \times 10^{4}$ & $1 \times 10^{4}$ \\
\hline
\end{tabular}

*No colonies could be detected on the plates. 
Table 3. Incidence of gelE, asal, esp and cylA genes could be detected in E. faecalis and E. faecium isolated from examined sample

\begin{tabular}{|c|c|c|c|c|c|c|c|c|c|c|c|}
\hline \multirow{3}{*}{$\begin{array}{l}\text { Type of } \\
\text { samples }\end{array}$} & \multirow{3}{*}{$\begin{array}{l}\text { Enterococci } \\
\text { spp. }\end{array}$} & \multirow{2}{*}{\multicolumn{2}{|c|}{$\begin{array}{l}\text { No. of } \\
\text { isolated } \\
\text { strains }\end{array}$}} & \multicolumn{8}{|c|}{ Virulence genes } \\
\hline & & & & \multicolumn{2}{|c|}{ gelE } & \multicolumn{2}{|c|}{ asal } & \multicolumn{2}{|c|}{ esp } & \multicolumn{2}{|c|}{ cylA } \\
\hline & & No. & $\%$ & No. & $\%$ & No. & $\%$ & No. & $\%$ & No. & $\%$ \\
\hline \multirow{2}{*}{ Raw milk } & E. faecalis & 4 & 8 & 2 & 50 & 4 & 100 & 2 & 50 & 2 & 50 \\
\hline & E. faecium & 16 & 32 & 10 & 62.5 & 12 & 75 & 9 & 56.3 & 3 & 18.8 \\
\hline \multirow{2}{*}{$\begin{array}{l}\text { Large scale } \\
\text { yoghurt }\end{array}$} & E. faecalis & 4 & 16 & 2 & 50 & 3 & 75 & 3 & 75 & $\mathrm{~N}$ & $\mathrm{~N}$ \\
\hline & E. faecium & $\mathrm{N}$ & $\mathrm{N}$ & $\mathrm{N}$ & $\mathrm{N}$ & $\mathrm{N}$ & $\mathrm{N}$ & $\mathrm{N}$ & $\mathrm{N}$ & $\mathrm{N}$ & $\mathrm{N}$ \\
\hline \multirow{2}{*}{$\begin{array}{l}\text { Small scale } \\
\text { yoghurt }\end{array}$} & E. faecalis & 2 & 8 & 1 & 50 & 1 & 50 & 1 & 50 & 1 & 50 \\
\hline & E. faecium & 7 & 28 & 3 & 42.9 & 4 & 57.1 & 5 & 71.4 & 4 & 57.1 \\
\hline \multirow{2}{*}{ Kareish cheese } & E. faecalis & 2 & 8 & 1 & 50 & 1 & 50 & 2 & 100 & $\mathrm{~N}$ & $\mathrm{~N}$ \\
\hline & E. faecium & 9 & 36 & 2 & 22.2 & 7 & 77.8 & 3 & 33.3 & 4 & 44.4 \\
\hline \multirow{2}{*}{$\begin{array}{l}\text { Large scale Ice } \\
\text { cream }\end{array}$} & E. faecalis & 1 & 4 & 1 & 100 & 1 & 100 & 1 & 100 & 1 & 100 \\
\hline & E. faecium & $\mathrm{N}$ & $\mathrm{N}$ & $\mathrm{N}$ & $\mathrm{N}$ & $\mathrm{N}$ & $\mathrm{N}$ & $\mathrm{N}$ & $\mathrm{N}$ & $\mathrm{N}$ & $\mathrm{N}$ \\
\hline
\end{tabular}

On the contrary, esp gene was detected in all investigated $\mathrm{E}$. faecalis isolates obtained from Kareish cheese samples Table (3) and Figs (1\& 2). Lower incidence $(75 \%)$ obtained by Abdeen et al., (2016). Moreover, esp gene was detected in $33.3 \%$ of E. faecium isolates from Kareish cheese samples. Hosseini et al., (2016) could not detect esp in E. faecalis strains obtained from cheese but detect esp genes in $40 \%$ of $\mathrm{E}$. faecium. Although the esp gene was detected in all investigated $\mathrm{E}$. faecalis strains, it couldn't be located in E. faecium isolates obtained from large scale ice cream samples Table (3) and Figs (1\& 2). Cytolysin (cylA) is one of the best characterized enterococci virulence factors. It has $\beta$-haemolytic properties which considered undesirable in foods and their use as starters in food fermentation is not recommended (Fifadaraet al., 2003). The results achieved in Table (3) and Figs (1\&2) revealed that cyclA gene was found in 50 and $18.8 \%$ of $\mathrm{E}$. faecalis and $\mathrm{E}$. faecium strains isolated from raw milk, respectively. Higher incidence of cyclA gene in E. faecalis isolates obtained by Gomes et al., (2008) as they found cylA in $88 \%$ of the obtained isolates, while Hussein (2013) detect lower incidence of cylA gene $(25 \%)$. In yoghurt samples it was found that cyclA gene was detected in 16.7 and $57.1 \%$ of $E$. faecalis and $E$. faecium, respectively. Abd El Tawab et al., (2016) couldn't detect cyclA gene in E. faecalis obtained from yoghurt samples. 


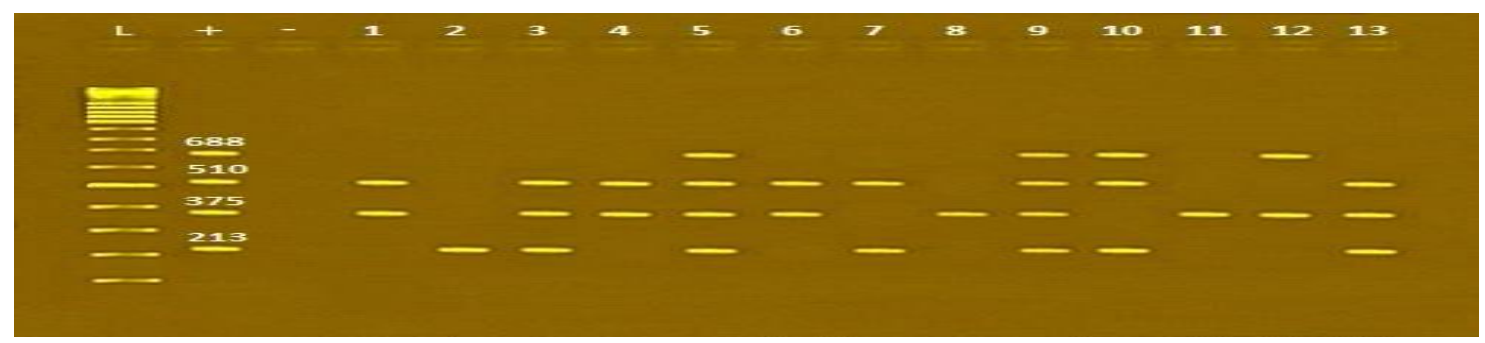

Fig. 1. Detection of gelE(213 bp), asal (375 bp), esp (510 bp) and cylA (688 bp) encoded virulence genes of $E$. faecalis strains isolated from the examined samples by multiplex PCR*Lane (L) (DNA ladder 1000 bp), ${ }^{*}$ Lane $(+)$ (positive control)*Lane (-) (negative control)*Lanes 8, 9, 12 and13: DNA of E. faecalis strains isolated from raw milk samples, ${ }^{*}$ Lanes $1,2,3,4,10$ and 11: DNA of $E$. faecalis strains isolated from yoghurt samples, ${ }^{*}$ Lanes 6 and 7: DNA of $E$. faecalis strains isolated from Kareish cheese samples, ${ }^{*}$ Lane 5: DNA of E. faecalis strains isolated from large scale ice cream samples.

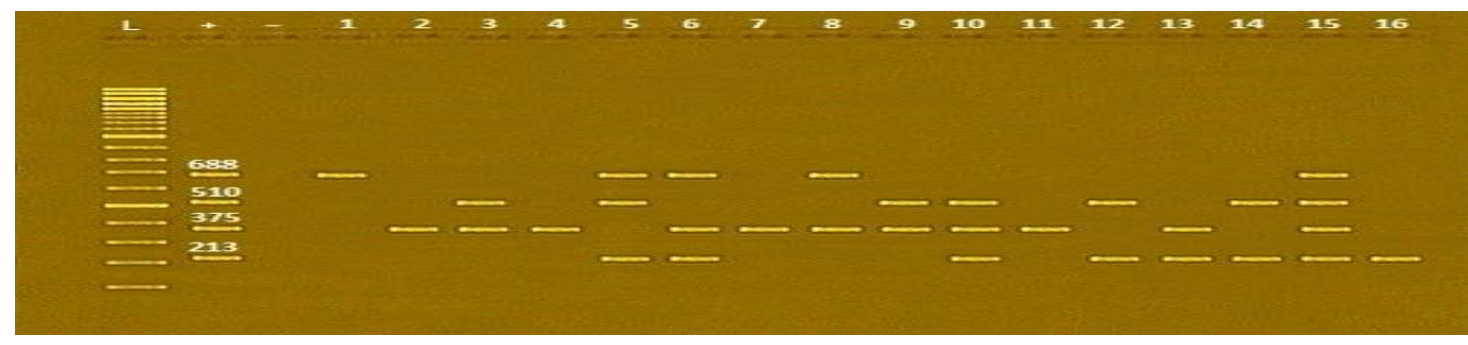

Fig. 2. Detection of gelE (213 bp), asal (375 bp), esp (510 bp) and cylA (688 bp) encoded virulence genes of $E$. faecium strains isolated from the examined samples by multiplex PCR*Lane (L) (DNA ladder $1000 \mathrm{bp}$ ), *Lane (+) (positive control) *Lane (-) (negative control) *Lanes 10- 16: DNA of E. faecium strains isolated from raw milk samples*Lanes 1- 9: DNA of $E$. faecium strains isolated from Kareish cheese samples.

Just like the finding in the present study and presented in Table (3) and Figs (1 $\& 2$ ), none of $E$. faecalis isolated from Kareish cheese samples and obtained by and Abdeen (2016) submitted to PCR harbored cycl Agene. All the investigated E. faecalis isolates obtained from large scale ice cream was found to carry cylA gene, while none of E. faecium strains had cyclA gene Table (3) and Figs (1 \& 2).

\section{Acknowledgments}

We are sincerely grateful for the help provided by all staff members of the Department of Food Hygiene, Faculty of Veterinary Medicine, South Valley University, Egypt

\section{References}

American Public Health Association (1992). Compendium of Methods for the Microbiological 
Examination of Foods. 16 th Ed., Washington D.C., USA.

Abd ElAal SF (2008). Microbiological research on some dairy products. Assiut Veterinary Medicine Journal, 54: 54-68.

Abd El-Hameid KG (2002). Studies on the sanitary conditions of raw milk in Qena Governorate. Master of Veterinary Sciences Thesis, Faculty of Veterinary Medicine, Assiut University, Egypt.

Abd El-Rahman AM (2010). Relation between E-coli, Enterococci and Cl. Perfringensas fecal contaminants in milk and some milk products. Master of Veterinary Sciences Thesis, Faculty of Veterinary Medicine, Assiut University, Egypt.

Abdeen EE, Hussien H, Hussan Z, Abdella W (2016). Genotyping and virulence genes of Enterococcus faecalis isolated form Kareish cheese and minced meat in Egypt. Research Journal of Microbiology, 11: 133-138.

Abd El Tawab AA, Ammar AM, Abd El-Hamid MI, El-Dessouky EN (2016). Virulence Genotyping of Enterococcus species isolated from meat and milk products. Benha Veterinary Medicine Journal, 31: 158-164.

El-Leboudy AA, Amer AA, El-Gaml AM, Shahin HF (2015). Sanitary Evaluation of Curd Dairy Products. Alexandria Journal of Veterinary Sciences, 45: 51-56.

Al-Hawary II (2000). The importance of Enterococci as a microbiological criterion from yoghurt. Suez Canal Veterinary Medicine Journal, 3: 29-35.
Angelotti R, Lewis KM, Foster MJ (1963). Faecal Streptococci in foods. Time temperature effects on behaviour in refrigerated foods and at warm holding temperature. Journal of Milk and Foods Technology, 206: 296-301.

Barbosa J, Gibbs PA, Teixeira P (2010). Virulence factors among Enterococci isolated from traditional fermented meat products produced in the North of Portugal. Food Control, 21: 651656.

Brooks DE (1974). Enterococci as fecal indicators in dairy products. 19th Ed., International Dairy Congress.

Coque T, Patterson J, Steckelberg J, Murray B (1995). Incidence of hemolysin, gelatinase, and aggregation substance among Enterococci isolated from patients with endocarditis and other infections and from faeces of hospitalized and communitybased persons. Journal of Infectious Diseases, 171: 12231229.

Deibel RH, Hartman PA (1982). The Enterococci, In: Compendium of Methods for the Microbiological Examination of foods, 2nd Ed., Speck, M.L. (Ed.), APHA., Inc.

Dogru A, Gencay Y, Ayaz N (2010). Comparison of virulence gene profiles of Enterococcus faecium and Enterococcus faecalis chicken neck skin and feces isolates. Kafkas Üniversitesi Veteriner Fakültesi Dergisi, 16: 129-133.

El-Ansary, Maria A (2014). Assessment of Microbiological Quality of Yoghurt Sold in El- 
Behera Governorate. Alexandria Journal of Veterinary Sciences, 43: 52-57.

Elmali M, Hayriye YC (2018). The prevalence, vancomycin resistance and virulence gene profiles of Enterococcus species recovered from different foods animal origin Veterinary Archive, 88: 111-124.

El-Malt LM, Abdel Hameed KG, Ahmed AS (2013a). Microbiological quality assessment of ice cream products in Qena Faculty of Veterinary Medicine, South Valley University, Qena, Egypt Zagazig Veterinary Journal, 41: 775-783.

El-Malt LM, Abdel Hameed KG, Ahmed AS (2013b). Microbiological evaluation of yoghurt products in Qena city, Egypt. Veterinary World, 6: 400404.

Fifadara N, Radu S, Hassan Z, Beuchat LR, Rusul G (2003). Hemolytic and non-hemolytic vancomycin resistant Ent. faecium isolated from beef imported to Malaysia. Journal of Food Products, 66: 1845-1850 .

Foulquie MMR, Sarantinopoulos P, Tsakalidou E, DeVuyst L (2006).

The role and application of Enterococci in food and health. International Journal of Food Microbiology, 106: 1-24.

Franz CM, Holzapfel WH, Stiles ME (1999). Enterococci at the crossroads of food safety. International Journal of Food Microbiology, 47: 1-24.

Franz CM, Muscholl-Silberhorn AB, Yousif NM, Vancanneyt M, Swings JWH (2001). Incidence of virulence factors and antibiotic resistance among Enterococci isolated from food. Applied and Environmental Microbiology, 67: 4385-4389 .

Giraffa G (2002). Enterococci from foods. FEMS Microbiology Review, 26: 163-171.

Gorgy FS, El Asuoty MS, Saber AS, Abeer HA (2016). Prevalence of Enterococci and Streptococci in Raw Milk and Some Dairy Products and The Subsequent Alteration on Quality. Damanhour branch \& Alexandria branch AHRI, Egyptian Journal of Chemistry and Environmental Health, 2: 500-515.

Gomes BC, Esteves CT, Palazzo IC, Darini AL, Felis GE, Sechi LA, Franco BD, DeMartinis EC (2008). Prevalence and characterization of Enterococcus spp. isolated from Brazilian foods. Food Microbiology, 25: 668-675

Hammad AM, Hassan HA, Shimamoto $T$ (2015). Prevalence, antibiotic resistance and virulence of Enterococcus spp. in Egyptian fresh raw milk cheese. Food Control, 50: 815-820.

Hamzah AM, Kadim HK (2018). Isolation and identification of Enterococcus faecalis from cow milk samples and vaginal swab from human. Journal of Entomology and Zoology Studies, 6:218-222.

Hosseini SM, Zeyni B, Rastyani S, Jafari R, Shamloo F, Tabar ZK Arabestani MR (2016). Presence of virulence factors and antibiotic resistances in Enterococcus sp. collected from dairy products and meat. Hamadan University of 
Medical Sciences, Hamadan, IR Iran, 8: 138-145.

Hussein AN (2013). Detection of some virulence factors of Enterococcus faecalis isolated from raw milk by Multiplex PCR. Journal of AlQadisiya for science, 18: 132144.

Hussien MF, Amin MM, Sadek OA (2013). Comparison between the microbiological quality of Kareish cheese manufactured from raw and pasteurized skimmed milk sold in Assiut city markets. Assiut Veterinary Medicine Journal, 59: 129-137.

Inhoque RP, Prichula JN, Santestevan A, Pedro AA, Motta AS, Frazzon AG (2017). Virulence Profiles in Enterococcus spp. isolated from Raw Buffalo's Milk in South Brazil. Research Journal, 12: 248254.

Lampert LM (1975). Modern Dairy Products. 3rd Ed., Chemical Pub. Co., Inc., New York.

Lopez-Diaz TM, Santos JA, Gonzales CJ, Moreno B, Garcia ML (1995). Bacteriological quality of traditional Spanish blue cheese. Milchwissenschaft, 50: 503-505.

Manero A, Blanch AR (1999). Identification of Enterococcus spp. with a biochemical key. Applied Environmental Microbiology, 65: 4425-4430.

Mohammad AG (2015). Studies on harmful Enterococciin raw milk and some cheese varieties. Master of Veterinary Sciences Thesis, Faculty of Veterinary Medicine, Assiut University, Egypt.

Morrison D, Woodford N, Cookson B (1997). Enterococci as emerging pathogens of humans. Journal of Applied Microbiology, 83: 89-99.
Poh CH, Oh HML, Tan AL (2006). Epidemiology and clinical outcome of Enterococcalbacteraemia in an acute care hospital. Journal of Infectious diseases, 52: 383-386.

Roushdy IM, Ehrmann MA, Vogel RF (1998). Molecular identification and characterization of halotolerant lactic acid bacteria isolated from soft pickled Damietta cheese. Advanced Food Science, 20: 40-45.

Thurlow LR, Thomas VC, Hancock LE (2009). Capsular polysaccharide production in Enterococcus faecalisand contribution of $\mathrm{CpsF}$ to capsule serospecifity. Journal of Bacteriology, 191: 6203-6210.

Trivedi K, Cupakova S, Karpiskova R (2011). Virulence factors and antibiotic resistance in Enterococci isolated from foodstuffs. VeterinarniMedicina, 56: 352-357.

Vankerckhoven V, VanAutgaerden T, Vael C, Lammens C, Chapelle S, Rossi R, Jabes D, Goossens H (2004). Development of Multiplex PCR for the detection of asa1, gelE, cylA, esp and hylgenes in Enterococci and survey for virulence determinants among European hospital isolates of E.faecium. Journal of Clinical Microbiology, 42: 4473-4479.

VanTyne D, Gilmore MS (2014). Evolution of Enterococcal Virulence and antibiotic resistance. Annual Review of Micrbiology, 68: 337-356.

Willems R, Homan W, Top J, Santen MTD, Manzioros X, Gaillard C, Grauls C, Mascini E, VanKregten E, VanEmbden J, Bonten M (2001). Variant esp 
gene as a marker of a distinct genetic lineage of vancomycinresistant Enterococcus faecium spreading in hospitals. Lancet, 357: 853-855. 